\title{
ANXIETY DISORDERS AND THE FREQUENCY OF NEGATIVE THOUGHTS: A COMPARATIVE STUDY IN CHILDREN WITH AND WITHOUT SPECIAL LEARNING DISABILITIES
}

\author{
Giannouli Vasiliki' ${ }^{11}$, \\ Sarris Dimitrios², \\ Alexoudi Pagona ${ }^{3}$ \\ ${ }^{1}$ Assistant Professor, \\ Department of Special Education and Social Policy, \\ Faculty of Social Humanities and Arts, \\ University of Macedonia, \\ Thessaloniki, Greece, Egnatia 156, 54636, \\ Greece \\ ${ }^{2}$ Assistant Professor, \\ Department of Preschool Education, \\ University of Ioannina, Epirus, \\ Greece \\ ${ }^{3}$ M.Sc in Special Education, \\ Faculty of Social Humanities and Arts, \\ University of Macedonia, \\ Thessaloniki, Greece, Egnatia 156, 54636,
}

Greece

\begin{abstract}
:
Special Learning Disabilities (SLD) are often accompanied by negative thoughts of selfassessment, deficits in social interactions and psycho-emotional problems as well, which hinder the development and the smooth integration of children diagnosed with SLD into their environment. This research attempts to investigate the association of negative selfassessment thoughts and anxiety disorders with Special Learning Disabilities in a sample of sixty Greek-speaking children in 4th, 5th and 6th grades with and without SLD, including their parents. The tools used for this purpose are the Children's Automatic Thoughts Scale (CATS), and the Spence Children's Anxiety Scale (SCAS-CH) self-report questionnaire, which assess anxiety disorders. Parents were asked to answer the corresponding Spence Children's Anxiety Scale-Parents Edition (SCAS-P) symptommonitoring questionnaire. According to the results compared to their normal development peers, children with SLD had a higher incidence of negative thoughts, which is more likely to lead to symptoms of anxiety disorders; their parents in fact were able to perceive the severity or frequency of these symptoms in their children. In addition, the frequency of negative thoughts and symptoms related to anxiety disorders seemed to
\end{abstract}

i Correspondence: email giannouliv@yahoo.com; sarrisdem@gmail.com; alexpagona@gmail.com 
be influenced by the student's condition (with or without SLD), but not by gender and age.

Keywords: special learning disabilities, anxiety disorders, negative thoughts

\section{Introduction}

In recent years more and more researchers (Swanson, Zheng, Jerman, 2009 \& Mather, Gregg, 2006) propose a more complex approach to the identification and diagnosis of SLD, which focuses on deficit observation in one or more cognitive areas: reading (decoding, fluency, understanding); written form of language (basic skills, fluency, utterance); or mathematics (basic skills, efficiency, application) by avoiding alternative explanations for this deficit (e.g. cognitive damage, or lack of education opportunities). In this research the term Special Learning Difficulties will be used adopting thus the suggestion of Kavale, Spaulding \& Beam (2009) in defining learning disabilities / disorders as follows: "SLD refers to heterogeneous clusters of disorders that significantly impede the normal progress of academic achievement in 2\%-3\% of the school population. The lack of progress is exhibited in school performance that remains below expectation for chronological and mental ages, even when provided with high-quality instruction. The primary manifestation of the failure to progress is significant underachievement in a basic skill area that is not associated with insufficient educational, interpersonal, cultural/familial, and/or sociolinguistic experiences. The primary severe ability achievement discrepancy is coincident with deficits in linguistic competence, cognitive functioning, neuropsychological processes (or any combination of such contributing deficits that are presumed to originate from central nervous system dysfunction)".

The research community converges on the definition of SLD as a group of neurobiological-based difficulties, which contains not only genetic but also epigenetic and environmental factors that influence the ability of the individual to process verbal and non-verbal information; and that definition is based on the revised version of the DSM-V. Nevertheless, one cannot fail to recognize that it is difficult to determine the exact percentage of these disabilities since the effort to better identify/diagnose them it still continues using many different assessment procedures (Pham \& Riviere, 2015; Polychroni, 2010; Tzouriadou, 2011). According to the international literature (American Psychiatric Association, 2013; Margari, Buttiglione, Craig, Cristella, de Giambatista, Matera, Operto \& Simon, 2013) the most probable percentage of people facing SLD is mentioned to be $5 \%$ to $15 \%$ of the school population. In Greece, students with SLD amount to about $56 \%$ of students with special needs (according to the most recent enumeration conducted by the Pedagogical Institute, Ministry of Education, 2004). In the same line researchers such as Maridakis-Kassotakis (2013) and Triga-Mertika (2010) seemed to agree on that ten (10) students out of thirty (30) of an ordinary school class could present SLD. The most difficulties appear in language courses at a percentage that reaches up to $80 \%$ of all children with SLD (Triga-Mertika, 2010). 
In addition to the aforementioned difficulties of students with SLD in language courses there are several studies that show that these students often experience increased psychological discomfort with severe psycho-emotional difficulties and existing deficits in their social cognitive and communication skills (Smith \& Alloy 2009; DeJong- Meyer \& Beck-Riede, 2009). Deficiencies in the interpretation of extralinguistic and metalinguistic elements, combined with reduced skills in working memory and information processing, turn out for these students to show a rigid and one-dimensional way of thinking and of handling various social conditions; additionally, they have the tendency to misinterpret situations, acting often in an inappropriate way (Rubin, Bukowsk \& Parker, 1998). More specifically, students with SLD have incomplete skills to initiate and maintain an interaction, as well as to initiate and carry on a dialogue. On the contrary, they prefer to answer in one word and do not use complete sentences with arguments to justify their choices. (Burton, Kagan \& Clements, 2013). Because of the above and according to Bukowski, Hoza and Boivin (1993) students with SLD often experience high levels of loneliness and low quality friendships.

There are also several studies reporting that the comorbidity of SLD with psychoemotional / behavioral disorders is usually the rule and not the exception (Zakopoulou, Mavreas, Christodoulides, Lavidas, Fili, Georgiou, Dimakopoulos \& Vergou, 2014). Students with SLD have a higher risk of developing depression and social isolation than their peers without similar problems and often have anxiety disorders, phobias and negative thoughts (Dalley, Bolocofsky, Alcorn \& Baker, 1992). According to Bijttebier, Raes, Vasey, Bastin and Ehring (2014), repetitive, automatic, negative thoughts in children and adults seem to be an important vulnerability to a variety of (emotional) problems, including depression, generalized anxiety disorder, social phobia, insomnia, and rumination. Rumination, defined as the cognitive process characterized by an arbitrary, repetitive way of thinking that focuses on negative emotions and thoughts; given this, it can be the generative cause of internalizing disorders, especially in children with SLD, as it is a mechanism for dealing with their difficulties in the school environment (Smith \& Alloy, 2009. Gibb, Grassia, Stone, Uhrlass, McGeary \& Brooding, 2012). Thus, in addition to school difficulties, children with SLD often experience psychological maladaptation, lower interpersonal self-esteem, anxiety symptoms, emotional withdrawal, and passivity (Polychroni, Koukoura \& Anagnostou, 2006).

A meta-analysis by Nelson \& Harwood, (2011) showed that approximately $70 \%$ of students with SLD experience higher levels of stress than those of their peers without SLD. Also, the research of Knivsberg \& Andreassen, (2011) and Achenbach, Dumenci and Rescola, (2003), in their attempt to correlate SLD with internalized or externalized behavioral problems, showed that the internalized problems of students with SLD mainly related to withdrawal, anxiety, depression, physical discomfort and phobias; on the other, their external problems mainly included deficits that were more obvious, such as their tendency to delinquency, aggression and anxiety.

In addition, studies by Visser, Kalmar, Linkersdorfer et al. (2020), as well as Mugnaimi, Lassi, LaMalfa and Albertini (2009), report that children with SLD, or other 
related problems, are more likely to develop a mental illness, including anxiety disorders, while the research by Bakker, Denessen, Bosman, Krijger \& Bouts, (2007) found a high correlation between SLD and negative self-assessment. Regarding the gender differences, girls with SLD appear to be more prone than boys to experiencing anxiety disorders (Schaefer, Watcins Burnham, 2003; Fisher, Schaefer, Watcins, Worell \& Hall, 2006). Also, according to Weems and Costa, (2005) children with SLD tend to be more vulnerable to failure and social criticism, showing symptoms of Social Disorder Anxiety, called otherwise as Social Phobia, while Carol and Iles, (2006) in their research found that SLD was more associated with Separation Anxiety. Respectively, the research of Mellon and Moutavelis (2007) with a sample of Greek students showed that the levels of stress that coexisted with SLD were negatively correlated even with school adjustment and performance, decreased though over time, with the sole exception of Social phobia, which followed an upward course. The research of Bozas, Bonti, Kouimtzi, Kyritsis and Karageorgiou (2016) was in the same line of results: it was found that students with SLD showed higher rates of antisocial behaviors or stressful outbursts, especially towards their peers, thus influencing key areas of their daily lives and their social acceptance and integration. Finally, in the most recent research by Visser and his colleagues (2020), the comorbidity rates of SLD were found to be around $21 \%$ for anxiety disorders, $28 \%$ for depression, 28\% for ADHD and 22\% for behavioral disorders.

In addition to the number of studies mentioned above that have focused on the coexistence of SLD and anxiety disorders in students, in recent years researchers have turned their attention to the parents of these children, who also appear to have higher levels of parenting stress, poorer reading history and they adopt different parental behavior patterns compared to parents of children with normal development (Bonifacci, Storti \& Tobia, 2015). Research by Brown-Jacobsen, Wallace \& Whiteside, (2011) showed that parents' observations and recordings were more accurate about their children's externalizing behaviors, while the children themselves usually provided more accurate descriptions of internalized anxiety symptoms. In addition, in the research of Chien and Lee (2013), it was observed that parents of children with SLD need further psychological assistance, guidance and information from mental health professionals and teachers, in order to provide useful and valuable information about the needs of their children.

Given that in the aforementioned literature, it has been observed that children with SLD are often possessed by negative thoughts that in turn can trigger anxiety disorders. The ultimate purpose of this study was to investigate the correlation between SLD and manifestation of anxiety problems and negative thoughts in a sample of Greekspeaking students in the fourth, fifth and sixth grades with and without SLD.

In particular, the aims were as follows:

a) To see whether the appearance of anxiety symptoms and anxiety problems would be related to SLD,

b) To see whether there would be a connection between negative thoughts and the appearance of anxiety symptoms in children with and without SLD, 
c) To see whether gender and age factors would influence the occurrence of anxiety problems in children with and without SLD,

d) To see whether the observations of parents and children with and without SLD would agree regarding the identification of anxiety symptoms?

\section{Sample of the research}

The ethical principles of the Declaration of Helsinki were followed, and an informed consent obtained from all the participants using the appropriate forms suggested by the World Medical Association. In total, the sample of the present study consisted of 60 children and 60 parents (one of the two parents of each participant). All children are students of the Greek public primary school attending 4th, 5th and 6th grades. The 30 children were students of normal development, while the remaining children were students with SLD. The sample consists of 30 boys, of whom 17 have SLD, while the remaining 13 do not. Respectively, out of the 30 girls who took part, 13 fall in the category of SLD, while the remaining 17 belong to the category of normal development. This division roughly represents the appearance of SLD in both sexes. In addition, out of the 30 students with SLD, 15 (50\%) had dyslexia, 5 (16.7\%) had difficulty with math (dyscalculia) and 10 (33.3\%) had a written expression disorder (dysorthographia). All of them had diagnosed by the Center of Educational and Counseling Support for children with Learning Disabilities (C.E.C. S.) -a center under the authorization and control of Greek Ministry of Education -sector of Special Education

\section{Tools}

Three tools were used for the research:

A. The Children's Automatic Thoughts Scale (CATS), which consists of four subscales and includes 40 questions. The original questionnaire developed and released from the Center for Emotional Health, Macquarie University, Sydney, Australia (2002). Its validation process has taken place in Australia including a sample of 765 children from 7-to-16 years old and in Holland in sample of 554 children aged from 8-18 years old (Schniering \& Rapee, 2020; Hogendoorn, Wolters, Vervoort, Prins, Boer, Kooij \& Haan, 2010). The four subscales consist of 10 statements each, and relate to negative thoughts of self-report as well as of externalization such as Physical Threat, Social Threat, Failure and finally Hostility. Specific CATS questions were drawn from self-report statements of children who were clinically anxious, or they had depression or other behavioral disorders (Schniering \& Rapee, 2002). Additionally, the scale focuses on describing thoughts rather than symptoms. CATS evaluates negative beliefs in both internalization and externalization problems. In Greece CATS has been translated and adapted in Greek sample by the Giannopoulou, Argalia \& Zafeiropoulou (2015). 
B. The Spence Children's Anxiety Scale (SCAS-CH). McCathie and Spence (1991) originally developed the SCAS questionnaire investigating the incidence of anxiety disorders. The Spence Children's Anxiety Test is a self-report questionnaire aimed at children and consists of six subscales of questions, each of which reflects the symptoms corresponding to symptoms of anxiety disorders, including panic attack and agoraphobia, separation anxiety disorder, obsessive/compulsive disorder, social phobia and generalized anxiety disorder. The SCAS-CH has been previously translated and adapted in Greek sample by Moutavelis \& Mellon (2005).

C. The Spence Children's Anxiety Scale Parents Edition (SCAS-P) questionnaire. Each parent of a child who was a sample member of this work was given the version of the Spence Children's Anxiety Scale specially designed for parents, since the form consists of 38 statements of monitoring of the corresponding anxiety disorders noted in the version for children, while the 6 positive predisposition propositions have been deliberately removed. These questions are similarly divided into 6 subgroups, each of which corresponds to a disorder under investigation (Panic / Agoraphobia, Separation Anxiety, Social Phobia, Fear of Physical Injury, Obsessive / Compulsive Disorder, Generalized Anxiety Disorder). The SCAS-P has also been translated and adapted in Greek sample by Moutavelis \& Mellon (2005), implementing the guidelines imposed by the International Committee of Tests (Hambleton \& Patsula, 1998; 2000; Van de Vijver \& Hambleton, 1996)

\section{Procedure for giving questionnaires}

The questionnaires were distributed to the sample respondents via personal e-mail, where they received a link to complete the electronic form created through Google Forms. In these forms there were also questions about the demographics of each participant, since due to the Covid-19 pandemic and the measures taken to limit the spread of the virus in the community, there was not the possibility of live communication with the respondents. Specifically, the record of the gender, age and existence or non-existence of Special Learning Disabilities of each child, as well as the gender of each parent was requested. The completion time did not exceed 20 minutes for each student and about 10 minutes for each parent.

\section{Results}

The reliability of the subscales of the three questionnaires was first checked by calculating Cronbach's alpha coefficient. As shown in Table 1 below all subscales were considered reliable. 
Table 1: Reliability of the three questionnaires CATS, SCAS - Children and SCAS - Parents

\begin{tabular}{|l|c|c|}
\hline CATS & Cronbach's alpha & Number of questions \\
\hline Physical Threat & 0.89 & 10 \\
\hline Social Threat & 0.93 & 10 \\
\hline Failure & 0.92 & 10 \\
\hline Hostility & 0.87 & 10 \\
\hline SCAS - Children & \multicolumn{2}{|l|}{} \\
\hline Panic - Agoraphobia & 0.85 & 9 \\
\hline Separation anxiety & 0.84 & 6 \\
\hline Social phobia & 0.81 & 6 \\
\hline Fear of Physical Injury & 0.75 & 6 \\
\hline Obsessive/Compulsive Disorder (OCD) & 0.88 & 6 \\
\hline GAD & 0.81 & 6 \\
\hline SCAS - Parents & \multicolumn{2}{|c|}{} \\
\hline Panic - Agoraphobia & 0.92 & 9 \\
\hline Separation anxiety & 0.78 & 6 \\
\hline Social phobia & 0.81 & 6 \\
\hline Fear of Physical Injury & 0.83 & 6 \\
\hline Obsessive/Compulsive Disorder (OCD) & 0.92 & 6 \\
\hline GAD & 0.89 & \multicolumn{2}{|c|}{} \\
\hline
\end{tabular}

Having ensured a considerable level of reliability for the three questionnaires, the next step was the comparison of children's responses with and without SLD on each questionnaire and its subscales. Tables $2 \& 3$ show that both children with SLD as a whole and their parents had scored higher on all three questionnaires than their normal development peers and their parents.

Table 2: Comparison of CATS subscales between children with and without SLD

\begin{tabular}{|c|c|c|c|c|c|}
\hline \multicolumn{2}{|c|}{ Children with SLD } & \multicolumn{2}{|c|}{ Children without SLD } & $\begin{array}{l}\text { Wilcoxon } \\
\text { Sum } \\
\text { RunTest } \\
\end{array}$ & $\begin{array}{c}\text { Level. } \\
\text { of } \\
\text { Significance } \\
\end{array}$ \\
\hline \multicolumn{2}{|l|}{ CATS } & \multicolumn{2}{|l|}{ CATS } & U-value & P-value \\
\hline $\begin{array}{l}\text { Physical Threat } \\
\text { [Measure of position / } \\
\text { Dispersion measure] }\end{array}$ & $\begin{array}{l}14.63 \\
(8.54)\end{array}$ & $\begin{array}{l}\text { Physical Threat } \\
\text { [Position measure / } \\
\text { dispersion measure] }\end{array}$ & $\begin{array}{c}6.0 \\
(6.75)\end{array}$ & 212.0 & 0.001 \\
\hline $\begin{array}{l}\text { Social Threat } \\
\text { [Measure of position / } \\
\text { Dispersion measure] }\end{array}$ & $\begin{array}{l}19.27 \\
(7.36)\end{array}$ & $\begin{array}{l}\text { Social Threat } \\
\text { [Measure of position / } \\
\text { Dispersion measure] }\end{array}$ & $\begin{array}{c}7.5 \\
(5.0)\end{array}$ & 144.5 & 0.001 \\
\hline $\begin{array}{l}\text { Failure } \\
\text { [Measure of position / } \\
\text { Dispersion measure] }\end{array}$ & $\begin{array}{l}14.17 \\
(8.72)\end{array}$ & $\begin{array}{l}\text { Failure } \\
\text { [Measure of position / } \\
\text { Dispersion measure] }\end{array}$ & $\begin{array}{c}4.0 \\
(8.75)\end{array}$ & 226.5 & 0.001 \\
\hline $\begin{array}{l}\text { Hostility } \\
\text { [Measure of position / } \\
\text { Dispersion measure] }\end{array}$ & $\begin{array}{l}18.47 \\
(6.98)\end{array}$ & $\begin{array}{l}\text { Hostility } \\
\text { [Measure of position / } \\
\text { Dispersion measure] }\end{array}$ & $\begin{array}{c}7.5 \\
(7.0)\end{array}$ & 138.5 & 0.001 \\
\hline
\end{tabular}

Specifically in Table 2, where the Wilcoxon Sum Rank Test was used, with the values of the subscales not normally distributed in both categories (Shapiro-Wilktest, p-value $<0.05)$, a statistically significant difference was observed in the subscales: Physical Threat $(\mathrm{U}=212.0, \mathrm{p}<0.001)$, Social Threat $(\mathrm{U}=144.5, \mathrm{p}<0.001)$, Failure $(\mathrm{U}=22.5, \mathrm{p}<0.001)$, and 
Hostility $(\mathrm{U}=138.5, \mathrm{p}<0.001)$. Children with SLD showed statistically significantly higher values in all subscales of CATS questionnaire compared to children without SLD.

Table 3: Comparison of SCAS-CH subscales between children with and without SLD

\begin{tabular}{|c|c|c|c|c|c|}
\hline \multicolumn{2}{|c|}{ Children with SLD } & \multicolumn{2}{|c|}{ Children without SLD } & $\begin{array}{c}\text { Wilcoxon } \\
\text { Sum Run } \\
\text { Test } \\
\end{array}$ & $\begin{array}{c}\text { Level } \\
\text { of } \\
\text { significance } \\
\end{array}$ \\
\hline \multicolumn{2}{|l|}{ SCAS CH } & \multicolumn{2}{|l|}{ SCAS CH } & $\mathrm{U} / \mathrm{t}-$ & p-value \\
\hline $\begin{array}{l}\text { Panic / Agoraphobia } \\
\text { [Measure of position / } \\
\text { Dispersion measure] }\end{array}$ & $\begin{array}{c}9.7 \\
(5.25)\end{array}$ & $\begin{array}{l}\text { Panic / Agoraphobia } \\
\text { [Measure of position / } \\
\text { Dispersion measure] }\end{array}$ & $\begin{array}{c}3.9 \\
(2.31)\end{array}$ & -5.54 & 0.001 \\
\hline $\begin{array}{l}\text { Separation anxiety } \\
\text { [Measure of position / } \\
\text { Dispersion measure] }\end{array}$ & $\begin{array}{c}7.9 \\
(4.28)\end{array}$ & $\begin{array}{l}\text { Separation anxiety } \\
\text { [Measure of position / } \\
\text { Dispersion measure] }\end{array}$ & $\begin{array}{c}4.7 \\
(3.5)\end{array}$ & -3.17 & 0.002 \\
\hline $\begin{array}{l}\text { Social phobia } \\
\text { [Measure of position / } \\
\text { Dispersion measure] }\end{array}$ & $\begin{array}{c}9.97 \\
(3.73)\end{array}$ & $\begin{array}{l}\text { Social phobia } \\
\text { [Measure of position / } \\
\text { Dispersion measure] }\end{array}$ & $\begin{array}{c}5.7 \\
(3.34)\end{array}$ & -4.67 & 0.001 \\
\hline $\begin{array}{l}\text { Fear of Physical Injury } \\
\text { [Measure of position / } \\
\text { Dispersion measure] }\end{array}$ & $\begin{array}{c}9.0 \\
(4.41)\end{array}$ & $\begin{array}{l}\text { Fear of Physical Injury } \\
\text { [Measure of position / } \\
\text { Dispersion measure] }\end{array}$ & $\begin{array}{c}5.0 \\
(3.75)\end{array}$ & 222.0 & 0.001 \\
\hline $\begin{array}{l}\text { Obsessive-Compulsive } \\
\text { Disorder (OCD) [Measure } \\
\text { of position / } \\
\text { Dispersion measure] }\end{array}$ & $\begin{array}{c}7.17 \\
(4.46)\end{array}$ & $\begin{array}{l}\text { Obsessive-Compulsive } \\
\text { Disorder (OCD) [Measure } \\
\text { of position / Dispersion } \\
\text { measure] }\end{array}$ & $\begin{array}{c}3.0 \\
(5.75)\end{array}$ & 304.0 & 0.031 \\
\hline $\begin{array}{l}\text { GAD } \\
\text { [Measure of position / } \\
\text { Dispersion measure] }\end{array}$ & $\begin{array}{c}7.97 \\
(3.68)\end{array}$ & $\begin{array}{l}\text { GAD } \\
\text { [Measure of position / } \\
\text { Dispersion measure] }\end{array}$ & $\begin{array}{c}4.77 \\
(3.04)\end{array}$ & -3.67 & 0.001 \\
\hline
\end{tabular}

Similarly in Table 3, the comparison of the subscales of the SCAS-Children questionnaire between children with and without SLD, revealed, statistically significant differences in the subscales Panic / Agoraphobia $(t=-5.54, p<0.001)$, Separation Anxiety $(t=-3.17, p<$ 0.001), Social Phobia $(t=-4.67, p<0.001)$, Fear of Physical Injuries $(U=222.0, p=0.031)$, Obsessive / Compulsive Disorder ( $\mathrm{U}=304.0, \mathrm{p}=0.031$ ), and Generalized Anxiety Disorder $(\mathrm{t}=-3.67, \mathrm{p}<0.001)$. Children with SLD showed higher values compared to their normal development peers.

In addition, in the open-ended question "Is there anything else that scares you? Please write" at the end of the questionnaire, 40 children answered "Yes". Specifically, 24 children with SLD (60\%) and 16 children of normal development (40\%), responded positively. The majority of responses for both groups of children concerned social criticism, rejection and feeling of shame and they showed them through expressions like "I don't want to make a fool of myself ", "I don't want to be considered stupid", and "I don't want to be without friends". In addition, the fear of physical injury was stated through expressions like "I am afraid of heights", "I fear that something might fall on me". Various other factors have been reported individually.

In order to compare the SCAS-Parents questionnaire subscales for parents with children with and without SLD, the Welch $t$ - test was used, in case the values of the subscales showed a smooth distribution, whereas the Wilcoxon Sum Rank test when the values of the subscales were not normally distributed. Table 4 shows the statistically 
significant differences in the subscales Panic / Agoraphobia $(U=194.5, p<0.001)$, Separation Anxiety $(t=-3.68, p<0.001)$, Social Phobia $(U=147.5, p<0.001)$, Natural Fear Injuries $(U=292.5 .0, p=0.02)$, Obsessive/Compulsive Disorder $(U=242.5, p=0.002)$, and Generalized Anxiety Disorder $(U=230.5, p=0.001)$. In this case, also the parents of children with SLD scored higher on the SCAS-Parents questionnaire subscales than the parents of children with normal development.

Table 4: Comparison of SCAS-P subscales between children with and without SLD

\begin{tabular}{|c|c|c|c|c|c|}
\hline \multicolumn{2}{|c|}{ Children with SLD } & \multicolumn{2}{|c|}{ Children without SLD } & $\begin{array}{c}\text { Wilcoxon } \\
\text { Sum Rank test } \\
\end{array}$ & $\begin{array}{c}\text { Sig. } \\
\text { Level }\end{array}$ \\
\hline \multicolumn{2}{|c|}{ SCAS- Parents } & \multicolumn{2}{|c|}{ SCAS -Parents } & $\mathrm{U} / \mathrm{t}$. & P-value \\
\hline $\begin{array}{l}\text { Panic / Agoraphobia } \\
\text { [Measure of position / } \\
\text { Dispersion measure] }\end{array}$ & $\begin{array}{c}8.8 \\
(5.57)\end{array}$ & $\begin{array}{l}\text { Panic / Agoraphobia } \\
\text { Measure of position / } \\
\text { Dispersion measure] }\end{array}$ & $\begin{array}{c}1.0 \\
(4.5)\end{array}$ & 194.5 & 0.001 \\
\hline $\begin{array}{l}\text { Separation anxiety } \\
\text { [Measure of position / } \\
\text { Dispersion measure] }\end{array}$ & $\begin{array}{c}8.63 \\
(3.66)\end{array}$ & $\begin{array}{l}\text { Separation anxiety } \\
\text { [Measure of position / } \\
\text { Dispersion measure] }\end{array}$ & $\begin{array}{c}5.43 \\
(3.05)\end{array}$ & -3.68 & 0.001 \\
\hline $\begin{array}{l}\text { Social phobia } \\
\text { [Measure of position / } \\
\text { Dispersion measure] }\end{array}$ & $\begin{array}{c}9.83 \\
(3.44)\end{array}$ & $\begin{array}{l}\text { Social phobia } \\
\text { [Measure of position / } \\
\text { Dispersion measure] }\end{array}$ & $\begin{array}{c}4.0 \\
(3.0)\end{array}$ & 147.5 & 0.001 \\
\hline $\begin{array}{l}\text { Fear of Physical Injury } \\
\text { [Measure of position / } \\
\text { Dispersion measure] }\end{array}$ & $\begin{array}{c}8.0 \\
(4.28)\end{array}$ & $\begin{array}{l}\text { Fear of Physical Injury } \\
\text { [Measure of position / } \\
\text { Dispersion measure] }\end{array}$ & $\begin{array}{c}5.0 \\
(3.0)\end{array}$ & 292.5 & 0.02 \\
\hline $\begin{array}{l}\text { Obsessive-Compulsive } \\
\text { Disorder (OCD) } \\
\text { [Measure of position / } \\
\text { Dispersion measure] }\end{array}$ & $\begin{array}{c}6.93 \\
(4.81)\end{array}$ & $\begin{array}{l}\text { Obsessive-Compulsive } \\
\text { Disorder (OCD) } \\
\text { [Measure of position / } \\
\text { Dispersion measure] }\end{array}$ & $\begin{array}{c}2.0 \\
(5.75)\end{array}$ & 242.5 & 0.002 \\
\hline $\begin{array}{l}\text { ГA } \Delta \text { (GAD) } \\
\text { [Measure of position / } \\
\text { Dispersion measure] }\end{array}$ & $\begin{array}{c}6.6 \\
(3.89)\end{array}$ & $\begin{array}{l}\Gamma A \Delta(G A D) \\
\text { [Measure of position / } \\
\text { Dispersion measure] }\end{array}$ & $\begin{array}{c}2.0 \\
(4.75)\end{array}$ & 230.5 & 0.001 \\
\hline
\end{tabular}

In order to investigate whether the age, and the presence or absence of SLD, influence or further differentiate the sample responses, we used the multivariate ANOVA analysis. Table 5 shows a statistically significant effect only on category student (with or without SLD) on the subscales of the CATS questionnaire: Physical Threat $(\mathrm{F}=14.449, \mathrm{p}<0.001)$, Social Threat $(\mathrm{F}=25.55, \mathrm{p}<0.001)$, Failure $(\mathrm{F}=9.239, \mathrm{p}=0.004)$, and Hostility $(\mathrm{F}=28.462$, $\mathrm{p}<0.001$ ) while no statistically significant effect of age was observed on any subscale.

Table 5: Effect of age on CATS subscales

\begin{tabular}{|l|l|c|c|c|c|}
\hline CATS & Factors & Df & MS & F & P-value \\
\hline \multirow{5}{*}{ Physical Threat } & Age & 1 & 0.6 & 0.011 & 0.916 \\
\cline { 2 - 5 } & Category student & 1 & 786.0 & 14.449 & $\mathbf{0 . 0 0 1}$ \\
\cline { 2 - 5 } & Age interaction with Category student & 1 & 13.9 & 0.255 & 0.616 \\
\hline \multirow{5}{*}{ Social Threat } & Age & 1 & 0.3 & 0.004 & 0.948 \\
\cline { 2 - 5 } & Category student & 1 & 1531.6 & 25.55 & $\mathbf{0 . 0 0 1}$ \\
\cline { 2 - 5 } & Age interaction with Category student & 1 & 47.5 & 0.793 & 0.377 \\
\hline \multirow{5}{*}{ Failure } & Age & 1 & 16.3 & 0.232 & 0.632 \\
\cline { 2 - 5 } & Category student & 1 & 651.2 & 9.239 & $\mathbf{0 . 0 0 4}$ \\
\cline { 2 - 5 } & Age interaction with Category student & 1 & 53.3 & 0.757 & 0.388 \\
\hline
\end{tabular}


A COMPARATIVE STUDY IN CHILDREN WITH AND WITHOUT SPECIAL LEARNING DISABILITIES

\begin{tabular}{|l|l|c|c|c|c|}
\hline \hline \multirow{3}{*}{ Hostility } & Age & 1 & 13.0 & 0.297 & 0.588 \\
\cline { 2 - 6 } & Category student & 1 & 1246.6 & 28.462 & $\mathbf{0 . 0 0 1}$ \\
\cline { 2 - 6 } & Age interaction with Category student & 1 & 9.0 & 0.205 & 0.652 \\
\hline
\end{tabular}

Similarly, in the SCAS-CH questionnaire table (6), a statistically significant effect of the Category student was observed on the subscales: Panic / Agoraphobia $(\mathrm{F}=31.52, \mathrm{p}<$ 0.001), Separation Anxiety $(F=10.72, p=0.001)$, Social Phobia $(F=22.888, p<0.001)$, Fear of Physical Injury $(\mathrm{F}=11.85, \mathrm{p}=0.001)$, Obsessive / Compulsive Disorder $(\mathrm{F}=4.055, \mathrm{p}=$ $0.049)$ and Generalized Anxiety Disorder $(F=13.793, p<0.001)$. The only statistically significant interaction of age with the Category student on the Social Phobia subscale (F $=4.341, \mathrm{p}=0.042)$ means that the values on this subscale in relation to age depend on the Category student.

Table 6: Effect of age on SCAS-CH subscales

\begin{tabular}{|c|c|c|c|c|c|}
\hline SCAS - Children & Factors & Df & MS & $\mathbf{F}$ & P-value \\
\hline \multirow{3}{*}{$\begin{array}{l}\text { Panic/ } \\
\text { Agoraphobia }\end{array}$} & Age & 1 & 3.4 & 0.211 & 0.647 \\
\hline & Category student & 1 & 506.5 & 31.52 & 0.001 \\
\hline & Age interaction with Category student & 1 & 47.9 & 2.981 & 0.09 \\
\hline \multirow{3}{*}{$\begin{array}{l}\text { Separation } \\
\text { anxiety }\end{array}$} & Age & 1 & 35.79 & 2.45 & 0.123 \\
\hline & Category student & 1 & 156.67 & 10.72 & 0.001 \\
\hline & Age interaction with Category student & 1 & 28.05 & 1.92 & 0.171 \\
\hline \multirow{3}{*}{$\begin{array}{l}\text { Social } \\
\text { phobia }\end{array}$} & Age & 1 & 2.86 & 0.239 & 0.627 \\
\hline & Category student & 1 & 274.31 & 22.888 & 0.001 \\
\hline & Age interaction with Category student & 1 & 52.02 & 4.341 & 0.042 \\
\hline \multirow{3}{*}{$\begin{array}{l}\text { Fear of } \\
\text { Physical Injury }\end{array}$} & Age & 1 & 16.86 & 1.115 & 0.296 \\
\hline & Category student & 1 & 179.1 & 11.85 & 0.001 \\
\hline & Age interaction with Category student & 1 & 29.61 & 1.96 & 0.167 \\
\hline \multirow{3}{*}{$\begin{array}{l}\text { Obsessive / } \\
\text { Compulsive } \\
\text { Disorder (OCD) }\end{array}$} & Age & 1 & 19.15 & 0.942 & 0.336 \\
\hline & Category student & 1 & 82.44 & 4.055 & 0.049 \\
\hline & Age interaction with Category student & 1 & 0.97 & 0.048 & 0.828 \\
\hline \multirow[t]{3}{*}{ GAD } & Age & 1 & 5.22 & 0.472 & 0.495 \\
\hline & Category student & 1 & 152.52 & 13.793 & 0.001 \\
\hline & Age interaction with Category student & 1 & 36.93 & 3.339 & 0.073 \\
\hline
\end{tabular}

To investigate further the relationship between Social Phobia and the age of students, the Welch t-test was applied. Then, a statistically significant difference was observed in the mean value of the Social Phobia scale of the SCAS-Children questionnaire between children with SLD and without SLD of age 10 to 11 years. In this case, children with SLD show higher values compared to their peers without SLD.

Table 7: Relationship between social phobia and sample age

\begin{tabular}{|c|c|c|c|c|c|}
\hline \multicolumn{2}{|c|}{ Social phobia } & \multicolumn{2}{|c|}{ SLD (mean) } & \multirow[b]{2}{*}{$T$} & \multirow[b]{2}{*}{ p-value } \\
\hline & & No & Yes & & \\
\hline \multirow[t]{3}{*}{ Age } & 10 & 5.231 & 11.143 & -3.4246 & 0.005 \\
\hline & 11 & 5.250 & 10.667 & -4.3917 & 0.001 \\
\hline & 12 & 6.308 & 7.625 & -0.92432 & 0.368 \\
\hline
\end{tabular}


Finally, the investigation of the effects of age on the sample members' responses to the SCAS-P questionnaire, addressed to parents, showed (see Table 8) a statistically significant effect of the Category student (with or without SLD) on the subscales Panic / Agoraphobia $(\mathrm{F}=12.183, \mathrm{p}<0.001)$, Separation Anxiety $(\mathrm{F}=14.661 \mathrm{p}<0.001)$, Social Phobia $(\mathrm{F}=27.289, \mathrm{p}<0.001)$, Fear of Physical Injury $(\mathrm{F}=6.672, \mathrm{p}=0.012)$, Obsessive / Compulsive Disorder $(\mathrm{F}=9.498, \mathrm{p}=0.003)$ and Generalized Anxiety Disorder $(\mathrm{F}=10.703$, $\mathrm{p}=0.001)$. It showed also a statistically significant interaction of age with the Category student on the Physical Injury Fear subscale $(F=6.626, p=0.012)$, as the parents stated.

Table 8: Effect of age on SCAS-P subscales

\begin{tabular}{|c|c|c|c|c|c|}
\hline SCAS - Parents & Factors & Df & MS & $\mathbf{F}$ & P-value \\
\hline \multirow{3}{*}{$\begin{array}{l}\text { Panic/ } \\
\text { Agoraphobia }\end{array}$} & Age & 1 & 6.0 & 0.196 & 0.659 \\
\hline & Category student & 1 & 373.2 & 12.183 & 0.001 \\
\hline & Age interaction with Category student & 1 & 25.7 & 0.839 & 0.364 \\
\hline \multirow{3}{*}{$\begin{array}{l}\text { Separation } \\
\text { anxiety }\end{array}$} & Age & 1 & 20.57 & 1.934 & 0.17 \\
\hline & Category student & 1 & 155.94 & 14.661 & 0.001 \\
\hline & Age interaction with Category student & 1 & 39.79 & 3.741 & 0.058 \\
\hline \multirow{3}{*}{$\begin{array}{l}\text { Social } \\
\text { phobia }\end{array}$} & Age & 1 & 0.76 & 0.067 & 0.797 \\
\hline & Category student & 1 & 309.01 & 27.289 & 0.001 \\
\hline & Age interaction with Category student & 1 & 26.85 & 2.372 & 0.129 \\
\hline \multirow{3}{*}{$\begin{array}{l}\text { Fear of } \\
\text { Physical Injury }\end{array}$} & Age & 1 & 49.05 & 3.883 & 0.054 \\
\hline & Category student & 1 & 84.27 & 6.672 & 0.012 \\
\hline & Age interaction with Category student & 1 & 83.96 & 6.626 & 0.012 \\
\hline \multirow{3}{*}{$\begin{array}{l}\text { Obsessive / } \\
\text { Compulsive } \\
\text { Disorder (OCD) }\end{array}$} & Age & 1 & 0.02 & 0.001 & 0.976 \\
\hline & Category student & 1 & 198.02 & 9.498 & 0.003 \\
\hline & Age interaction with Category student & 1 & 0.61 & 0.029 & 0.865 \\
\hline \multirow[t]{3}{*}{ GAD } & Age & 1 & 0.86 & 0.064 & 0.80 \\
\hline & Category student & 1 & 143.76 & 10.703 & 0.001 \\
\hline & Age interaction with Category student & 1 & 4.06 & 0.302 & 0.585 \\
\hline
\end{tabular}

The application of the Welch t-test, as shown in Table 9, showed a statistically significant difference in the mean value of the Fear of Physical Injury subscale of the SCAS-Parents questionnaire, as stated by parents, between children with and without SLD of age 10 to 11 years, where statistically significantly higher values emerged.

However, no statistically significant difference was observed in the mean value of this subscale between children with and without SLD of age 10 to 12 years.

Table 9: Relationship between Physical Injury Fear and age

\begin{tabular}{|l|l|c|c|c|c|}
\hline \multicolumn{2}{|l|}{$\begin{array}{l}\text { Fear of Physical } \\
\text { Injury }\end{array}$} & \multicolumn{2}{|c|}{ SLD (mean) } & \multirow{2}{*}{$\begin{array}{c}\text { Level of Sig. } \\
\text { p-value }\end{array}$} \\
\cline { 3 - 6 } Age & $\mathbf{1 0}$ & 5.705 & 11.107 & -1.990 & 0.077 \\
\cline { 2 - 5 } & $\mathbf{1 1}$ & 5.667 & 8.100 & -4.535 & 0.002 \\
\cline { 2 - 5 } & $\mathbf{1 2}$ & 5.628 & 5.094 & 1.395 & 0.181 \\
\hline
\end{tabular}

Having observed that age did not influence the sample members' responses and did not show statistically significant effects on all three questionnaires, the existence of a gender- 
related effect was then investigated. In the analyses carried out, a statistically significant effect was observed only for the category group variable (SLD vs without SLD); however, nothing alike for gender was detected.

In a subsequent attempt to investigate the effect of age on the respective subgroups of boys and girls separately on all three questionnaires, we performed a series of ANOVA, which did not show significant effects of age. Only the effect of the group category itself was significant, (with ws without SLD). More specifically on the CATS questionnaire and in the boys subgroup, while a statistically significant difference was found in the mean value of the subscales Physical Threat $(F=10.30, p<0.004)$ Social Threat $(\mathrm{F}=21.822, \mathrm{p}<0.001)$ and Hostility $(\mathrm{F}=13.240, \mathrm{p}<0.001)$ among boys with and without SLD, no statistically significant effect of age was recorded on any subscale of the same questionnaire. Similarly in the girls subgroup while a statistically significant difference was found in the mean value of the same subscales, namely Physical Threat ( $\mathrm{F}$ $=5.191, \mathrm{p}<0.031)$ Social Threat $(\mathrm{F}=7.838, \mathrm{p}<0.010)$ and Hostility $(\mathrm{F}=13.285, \mathrm{p}<0.001)$ among girls with and without SLD, there was no statistically significant effect of age on any subscale of the questionnaire.

The same pattern of results was observed in the individual comparison of the two subgroups of boys and girls with and without SLD on the SCAS-CH questionnaire. In the subgroup of boys with and without SLD, while there was a statistically significant effect of the Category student on the subscales Panic / Agoraphobia $(\mathrm{F}=24.085$, p-value $<0.001)$, Separation Anxiety $(F=6.041, p$-value $=0.021)$ Social Phobia $(F=30.805, p$-value $<0.001)$, Fear of Physical Injury ( $F=15.601$, p-value $<0.001)$ and Generalized Anxiety Disorder ( $F$ $=13.155, \mathrm{p}$-value $=0.001)$, there was no statistically significant effect of Category student on the subscale Obsessive/Compulsive Disorder $(\mathrm{F}=3.593$, $\mathrm{p}$-value $=0.119)$, as well as no effect of age on any subscale. Respectively, in the subgroup of girls with and without SLD, a statistically significant effect of the Category student on the subscales Panic / Agoraphobia $(\mathrm{F}=9.827$, p-value $=0.004)$ and Social Phobia $(\mathrm{F}=4.247$, p-value $=0.049)$ was observed, while it was not found statistically significant effect of Category student on the subscales "Separation Anxiety" ( $F=3.938$, p-value = 0.058), "Fear of Physical Injury" ( $F=$ 2.403, p-value $=0.133)$, “Obsessive / Compulsive Disorder" $(\mathrm{F}=1.602$, p-value $=0.217)$, and "Generalized Anxiety Disorder" ( $F=3.755$, p-value = 0.064). The effect of age was not recorded on any subscale of the questionnaire.

The statistically significant effects of the category on all SCAS-CH subscales were further confirmed by other sub-comparisons. The application of the Wilcoxon Sum Rank test for the boys' group showed that the median of the Social Phobia subscale was statistically significantly higher in boys with SLD compared to boys without. The use of the Welch t-test also showed that the mean value of the subscales Panic / Agoraphobia, Separation Anxiety, Fear of Physical Injury and Generalized Anxiety Disorder was statistically significantly higher in boys with SLD than in their peers without similar difficulties. For the girls' group as well the same it was found: the mean value of the subscales Panic / Agoraphobia and Compulsive / Compulsive Disorder was statistically significantly higher in girls with SLD compared to girls without. 
Table 10: The median of SCAS-CH subscales in children with and without SLD

\begin{tabular}{|c|c|c|c|c|}
\hline SCAS - Children & $\begin{array}{c}\text { Without } \\
\text { SLD }\end{array}$ & $\begin{array}{l}\text { With } \\
\text { SLD }\end{array}$ & $t / U$ & $\begin{array}{l}\text { Level of Sig. } \\
\text { p-value }\end{array}$ \\
\hline \multicolumn{5}{|l|}{ Boys } \\
\hline $\begin{array}{l}\text { Panic / Agoraphobia } \\
\text { [Measure of position / } \\
\text { Dispersion measure] }\end{array}$ & $\begin{array}{c}2.85 \\
(1.99)\end{array}$ & $\begin{array}{c}9.65 \\
(4.69)\end{array}$ & -5.378 & 0.001 \\
\hline $\begin{array}{l}\text { Separation anxiety } \\
\text { [Measure of position / } \\
\text { Dispersion measure] }\end{array}$ & $\begin{array}{c}4.54 \\
(3.45)\end{array}$ & $\begin{array}{c}7.94 \\
(4.04)\end{array}$ & -2.483 & 0.019 \\
\hline $\begin{array}{l}\text { Social phobia } \\
\text { [Measure of position / } \\
\text { Dispersion measure] }\end{array}$ & $\begin{array}{c}5.0 \\
(4.0)\end{array}$ & $\begin{array}{l}11.0 \\
(6.0)\end{array}$ & 12.0 & 0.001 \\
\hline $\begin{array}{l}\text { Fear of Physical Injury } \\
\text { [Measure of position / } \\
\text { Dispersion measure] } \\
\end{array}$ & $\begin{array}{c}4.15 \\
(1.82)\end{array}$ & $\begin{array}{c}8.88 \\
(3.85)\end{array}$ & -4.451 & 0.001 \\
\hline $\begin{array}{l}\text { Obsessive-Compulsive Disorder (OCD) } \\
\text { [Measure of position / } \\
\text { Dispersion measure] }\end{array}$ & $\begin{array}{c}3.0 \\
(4.0)\end{array}$ & $\begin{array}{c}6.0 \\
(8.0)\end{array}$ & 69.5 & 0.089 \\
\hline $\begin{array}{l}\text { GAD } \\
\text { [Measure of position / } \\
\text { Dispersion measure] }\end{array}$ & $\begin{array}{c}3.69 \\
(2.43)\end{array}$ & $\begin{array}{c}7.76 \\
(3.33)\end{array}$ & -3.87 & 0.001 \\
\hline \multicolumn{5}{|l|}{ Girls } \\
\hline $\begin{array}{l}\text { Panic / Agoraphobia } \\
\text { [Measure of position / } \\
\text { Dispersion measure] }\end{array}$ & $\begin{array}{c}4.71 \\
(2.26)\end{array}$ & $\begin{array}{c}9.77 \\
(6.10)\end{array}$ & -2.848 & 0.013 \\
\hline $\begin{array}{l}\text { Separation anxiety } \\
\text { [Measure of position / } \\
\text { Dispersion measure] }\end{array}$ & $\begin{array}{c}4.82 \\
(3.63)\end{array}$ & $\begin{array}{c}7.85 \\
(4.74)\end{array}$ & -1.911 & 0.069 \\
\hline $\begin{array}{l}\text { Social phobia } \\
\text { [Measure of position / } \\
\text { Dispersion measure] }\end{array}$ & $\begin{array}{c}6.0 \\
(5.0)\end{array}$ & $\begin{array}{l}10.0 \\
(6.0)\end{array}$ & 65.5 & 0.061 \\
\hline $\begin{array}{l}\text { Fear of Physical Injury } \\
\text { [Measure of position / } \\
\text { Dispersion measure] } \\
\end{array}$ & $\begin{array}{c}6.0 \\
(3.0)\end{array}$ & $\begin{array}{c}8.0 \\
(7.0)\end{array}$ & 72.5 & 0.113 \\
\hline $\begin{array}{l}\text { Obsessive-Compulsive Disorder (OCD) } \\
\text { [Measure of position / } \\
\text { Dispersion measure] }\end{array}$ & $\begin{array}{c}5.35 \\
(4.49)\end{array}$ & $\begin{array}{c}7.31 \\
(3.71)\end{array}$ & -1.306 & 0.020 \\
\hline $\begin{array}{l}\text { GAD } \\
\text { [Measure of position / } \\
\text { Dispersion measure] }\end{array}$ & $\begin{array}{c}5.59 \\
(3.26)\end{array}$ & $\begin{array}{c}8.23 \\
(4.23)\end{array}$ & -1.869 & 0.075 \\
\hline
\end{tabular}

Finally, regarding the SCAS-Parents questionnaire in the subgroup of boys with and without SLD, a statistically significant effect of the Category student was found on the subscales Panic / Agoraphobia $(\mathrm{F}=12.295$, $\mathrm{p}$-value $=0.002)$, Separation Anxiety $(\mathrm{F}=$ 15.401, p-value $<0.001)$, Social Phobia $(F=33,669$, p-value $<0.001)$, Fear of Physical Injury $(\mathrm{F}=8.814, \mathrm{p}$-value $=0.006)$, Obsessive / Compulsive Disorder $(\mathrm{F}=4.598$, $\mathrm{p}$-value $=0.042)$ and Generalized Anxiety Disorder $(F=10.015$, $\mathrm{p}$-value $=0.004)$. However, there was no 
statistically significant effect of age on any subscale. Similarly, for the girls' subgroup a statistically significant effect of the Category student was recorded on the subscales Social Phobia $(\mathrm{F}=70.96$, $\mathrm{p}$-value $=0.013)$ and Obsessive/Compulsive Disorder $(\mathrm{F}=4.817$, $\mathrm{p}$-value $=0.037$ ). Additionally, no statistically significant effect was observed of the Category student on the subscales Panic / Agoraphobia $(\mathrm{F}=3.558$, p-value $=0.071)$, Separation Anxiety $(F=3.869$, p-value $=0.060)$, Fear of Physical Injury $(F=0.984$, p-value $=0.330)$ and Generalized Anxiety Disorder $(\mathrm{F}=3.286$, $\mathrm{p}$-value $=0.081)$. Age once again had no statistically significant effect.

Despite the lack of age effect on SCAS-P, the statistically significant effects of the category group on all SCAS-P subscales were further confirmed through individual comparisons. Thus, the use of the Wilcoxon Sum Rank Test for the boys' group showed that the median on the subscales of Panic / Agoraphobia, Fear of Physical Injury, Obsessive / Compulsive Disorder and Generalized Anxiety Disorder was statistically significantly higher in the parents of boys with SLD compared to the parents of boys without. Furthermore, according to the Welch t-test the mean value of the subscales Separation Anxiety and Social Phobia was statistically significantly higher in the parents of boys with SLD compared to the parents of boys without. For girls too, it was found that the median of the subscales Panic / Agoraphobia and Compulsive / Compulsive Disorder was statistically significantly higher in the parents of girls with SLD compared to the parents of girls who do not show SLD. Additionally, the use of Welch t-test showed that the mean value of the Social Phobia subscale was also statistically significantly higher in the parents of girls with SLD compared to the parents of girls without.

Table 11: The median of SCAS-P subscales in children with and without SLD

\begin{tabular}{|l|c|c|c|c|}
\hline SCAS - Parents & $\begin{array}{c}\text { Without } \\
\text { SLD }\end{array}$ & \multicolumn{1}{|l|}{$\begin{array}{c}\text { With } \\
\text { SLD }\end{array}$} & t/U & $\begin{array}{c}\text { Level of Sig. } \\
\text { p-value }\end{array}$ \\
\hline Boys & $1.0(3.0)$ & $7.0(8.0)$ & 29.0 & 0.001 \\
\hline $\begin{array}{l}\text { Panic / Agoraphobia } \\
\text { [Measure of position / } \\
\text { Dispersion measure] }\end{array}$ & $4.46(2.47)$ & $8.47(2.96)$ & -4.040 & 0.001 \\
\hline $\begin{array}{l}\text { Separation anxiety } \\
\text { [Measure of position / } \\
\text { Dispersion measure] }\end{array}$ & $4.08(2.56)$ & $9.59(2.67)$ & -5.729 & 0.001 \\
\hline $\begin{array}{l}\text { Social phobia } \\
\text { [Measure of position / } \\
\text { Dispersion measure] }\end{array}$ & $4.0(3.0)$ & $8.0(4.0)$ & 47.5 & 0.009 \\
\hline $\begin{array}{l}\text { Fear of Physical Injury } \\
\text { [Measure of position / } \\
\text { Dispersion measure] }\end{array}$ & $0.0(2.0)$ & $6.0(10.0)$ & 51 & 0.012 \\
\hline $\begin{array}{l}\text { Obsessive-Compulsive Disorder (OCD) } \\
\text { [Measure of position / } \\
\text { Dispersion measure] }\end{array}$ & $2.0(2.0)$ & $6.0(4.0)$ & 32.0 & 0.001 \\
\hline $\begin{array}{l}\text { GAD } \\
\text { [Measure of position / } \\
\text { Dispersion measure] }\end{array}$ & & & \\
\hline Girls & &
\end{tabular}




\begin{tabular}{|l|c|c|c|c|}
\hline \hline $\begin{array}{l}\text { Panic / Agoraphobia } \\
\text { [Measure of position / } \\
\text { Dispersion measure] }\end{array}$ & $2.0(4.0)$ & $9.0(8.0)$ & 58.0 & 0.030 \\
\hline $\begin{array}{l}\text { Separation anxiety } \\
\text { [Measure of position / } \\
\text { Dispersion measure] }\end{array}$ & $6.18(3.30)$ & $8.85(4.54)$ & -1.788 & 0.088 \\
\hline $\begin{array}{l}\text { Social phobia } \\
\text { [Measure of position / } \\
\text { Dispersion measure] }\end{array}$ & $6.24(3.60)$ & $10.15(4.34)$ & -2.637 & 0.015 \\
\hline $\begin{array}{l}\text { Fear of Physical Injury } \\
\text { [Measure of position / } \\
\text { Dispersion measure] }\end{array}$ & $6.47(3.91)$ & $7.92(4.91)$ & -0.876 & 0.394 \\
\hline $\begin{array}{l}\text { Obsessive-Compulsive Disorder (OCD) } \\
\text { [Measure of position / } \\
\text { Dispersion measure] }\end{array}$ & $2.0(5.0)$ & $6.0(4.0)$ & 62.5 & 0.045 \\
\hline $\begin{array}{l}\text { GAD } \\
\text { [Measure of position / } \\
\text { Dispersion measure] }\end{array}$ & $4.24(3.61)$ & $7.0(4.53)$ & -1.805 & 0.084 \\
\hline
\end{tabular}

Finally, in order to check the smooth correlation of the sample members' responses to the relevant subscales of the CATS - Physical Threat questionnaires, with the corresponding subscale in SCAS-Children - Fear of Physical Injury, and also the subscale of the SCASParents tool - Fear of Physical Injury, Spearman non-parametric linear correlation coefficient was used since the subscales' values are not normally distributed. According to Spearman correlation coefficient there is a moderate linear positive statistically significant correlation between the CATS-Physical Threat and SCAS-Parents-Physical Injury Fear ( $r s=0.410$, p-value $=0.001$ ) subscales and those of CATS-Physical Threat and SCAS -Children-Fear of Physical Injury ( $r s=0.532$, $\mathrm{p}$-value $<0.001$ ). A strong linear positive statistically significant correlation was also observed between the SCASChildren-Fear of Physical Injury and SCAS-Parents-Fear of Physical Injury subscales (rs $=0.764$, p-value $<0.001)$. Given that the correlations are positive, it turns out that the higher the prices in one subscale, the higher the prices in the other subscale.

Table 12: Correlation of similar subscales in CATS and SCAS-CH questionnaires

\begin{tabular}{|l|l|c|c|}
\hline & & $\begin{array}{c}\text { SCAS - } \\
\text { Parents - Fear of } \\
\text { Physical Injury }\end{array}$ & $\begin{array}{c}\text { CATS - } \\
\text { Physical } \\
\text { Threat }\end{array}$ \\
\hline $\begin{array}{l}\text { CATS - } \\
\text { Physical } \\
\text { Threat }\end{array}$ & Spearman Correlation Coefficient (rs) & 0.410 & \\
\cline { 2 - 4 } $\begin{array}{l}\text { SCAS - } \\
\begin{array}{l}\text { Children - Fear of } \\
\text { Physical Injury }\end{array}\end{array}$ & p-value & 0.001 & \\
\cline { 2 - 4 } & Spearman Correlation Coefficient (rs) & 0.764 & 0.532 \\
\hline
\end{tabular}



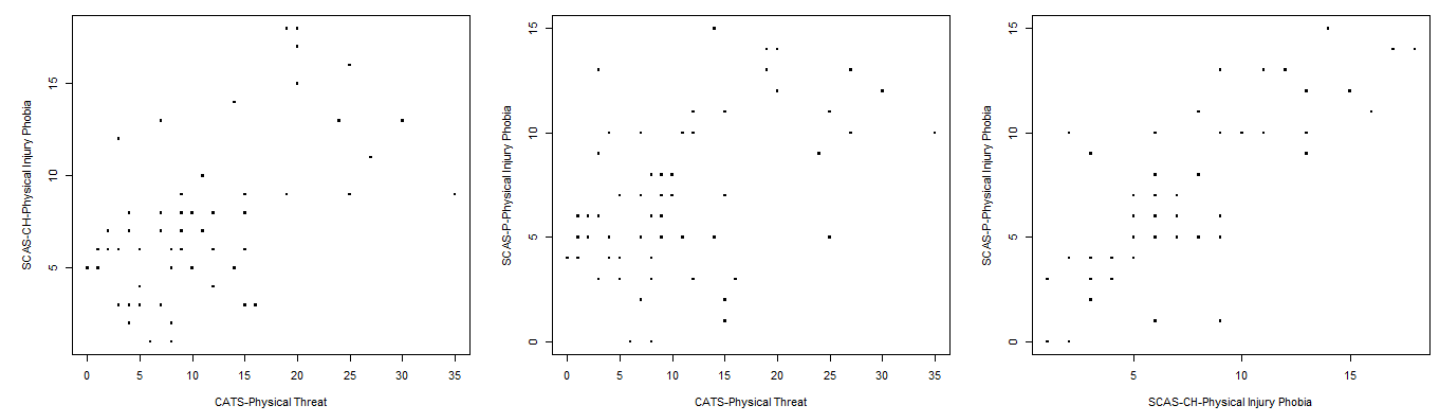

In order to correlate and find a relationship in the sample members' responses to the three questionnaires, the relevant subscales of CATS-Social Threat, SCAS-ChildrenSocial Phobia and SCAS-Parents-Social Phobia were further investigated. Specifically, the non-parametric linear correlation coefficient of Spearman was used in this case as well because the values of the subscales are not normally distributed. According to this correlation coefficient there is a strong linear positive statistically significant correlation between the CATS-Social Threat and SCAS-Children - Social Phobia ( $\mathrm{rs}=0.834$, pvalue $<0.001$ ) CATS-Social Threat and SCAS-Parents-Social Phobia ( $r$ = 0.779, p-value $<0.001$ ) subscales and between those of SCAS-Children-Social Phobia and SCAS-ParentsSocial Phobia ( $\mathrm{rs}=0.793$, p-value $<0.001$ ). Given that the correlations are positive, it turns out that the higher the prices in one subscale, the higher the prices in the other subscale.

Table 13: Correlation of similar subscales in CATS and SCAS-P questionnaires

\begin{tabular}{|l|l|c|c|}
\hline & & $\begin{array}{c}\text { SCAS-Parents - } \\
\text { Social Phobia }\end{array}$ & $\begin{array}{c}\text { CATS - } \\
\text { Social Phobia }\end{array}$ \\
\hline $\begin{array}{l}\text { CATS - } \\
\text { Social } \\
\text { Phobia }\end{array}$ & Spearman Correlation Coefficient (rs) & 0.779 & \\
\cline { 2 - 4 } & p-value & $<0.001$ & \\
\hline $\begin{array}{l}\text { SCAS } \\
\text { Children - } \\
\text { Social Phobia }\end{array}$ & Spearman Correlation Coefficient (rs) & 0.793 & 0.834 \\
\cline { 2 - 4 } & p-value & $<0.001$ & $<0.001$ \\
\hline
\end{tabular}
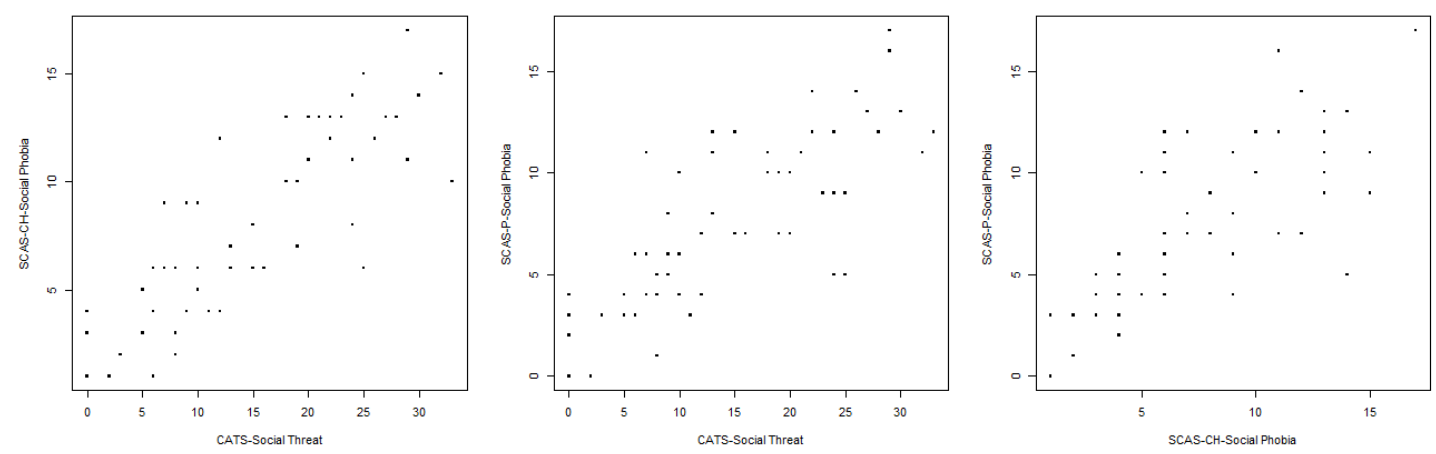


\section{Discussion}

Having mainly highlighted through the review of the international literature the correlation between Special Learning Disabilities with anxiety disorders and negative thoughts in students, the present study sheds a little more light on the degree and intensity of the coexistence of these difficulties by working on a sample of Greekspeaking students with and without SLD. Needless to say that this study offers a lot since the corresponding number of Greek surveys is very limited.

The study of the existing data managed to show satisfactory and interesting results in relation to the research questions posed in the present research. Regarding the first research question "Is the appearance of anxiety symptoms and anxiety problems related to SLD?", due to the answers of the Greek-speaking students with SLD who filled in the SCAS-CH questionnaire, it was found the following: they appear to have a higher incidence of symptoms related to Panic / Agoraphobia, Separation Anxiety, Social Phobia, Fear of Physical Injury, Obsessive / Compulsive Disorder and Generalized Anxiety Disorder, compared to their peers without similar difficulties. The results of the present study are in full agreement with previous research, which emphasize that the particularly psycho-emotional and social profiles of students with SLD, their negative experiences in the school environment, and also their intense and arduous efforts to keep up with school, are related with a state of intense stress (Nelson \& Harwood, 2011; Lipscomb et al., 2012; Visser et al., 2020).

Students with SLD are more prone and vulnerable to the onset of anxiety symptoms due to the learning difficulties they have and their socially unpleasant experiences. Even children and adolescents of normal development who meet difficulties or problems in their daily lives tend to exhibit increased anxiety problems. (Mugnaimi et al., 2009). It is no coincidence, after all, that the percentages of children with SLD in the open-ended question of the SCAS-CH questionnaire, who were asked to report anything else that frightens them and how often, are significantly higher than those of their normal development peers. Although there was no clear difference in the individual scales of the SCAS-CH questionnaire, from the answers of the sample members to the open-ended question, we understand that the fear of Social Criticism and Physical Injury are the categories that gathered the most answers in the category of children with and without SLD and therefore concern more the whole student community. This finding is in line with the findings of Weems and Costa (2005), and Li and Morris (2007), who emphasize that Social Phobia is particularly prevalent in children with SLD, as they repeatedly experience failure and often receive negative comments from their classmates and friends due to their inability to keep up with the majority in their educational responsibilities. As a result, social exposure seems to be an unpleasant situation for them.

Proceeding to the investigation of the research question «Are gender and age factors that influence the occurrence of anxiety problems in children with and without SLD?", an attempt was made to determine whether these factors play an important role 
in the occurrence of anxiety symptoms in children aged 10, 11 and 12 years old, apart from the factor category (SLD or not).

Starting with the age parameter, no statistically significant influence on any subscale of the CATS questionnaire regarding negative self-report thoughts was observed. The effect of the Category student mainly influenced the findings of the analysis, confirming once again what was mentioned above, that is children with SLD show more severe symptoms of anxiety, compared to their normal development classmates. However, in the SCAS-CH questionnaire an exception is the case of Social Phobia. Social Phobia at the ages of 10 and 11 years is on the rise, but it seems to have no significant influence at the age of 12. This result is consistent with the findings of Spence research (1998), which after applying the same tool showed that the symptoms of Social Phobia peak between the ages of 9 and 11 years.

On the contrary, other studies underline the influence of age only on comparisons with older children. Thus, it might be the case where only when a child enters adolescence that the demands of the social, family and school environment increase in conjunction with the biological changes that take place in the child's body; the child is forced somehow to experience more stress/pressure and possibly show a tendency to avoid any form of social exposure (Thaler, Kazemi \& Wood, 2010). Given that, the fact that the responses of the various age groups that participated in the present study were not different, could also be justified by the small age range of children combined with the limited number of participants in the study.

A similar effort to investigate the effect of gender on the occurrence of symptoms for anxiety disorders in childhood was made. On all subscales of CATS, SCAS-CH, and SCAS-P questionnaires, gender did not appear to play a significant role in the sample members' responses. This result contradicts the findings of similar studies, which emphasize the tendency of girls to have more frequent and more severe anxiety symptoms in childhood (Spence, 1998; Mellon \& Moutavelis, 2007).

However, when we individually compared boys and girls with and without SLD, then some differences emerged after children filled in the SCAS-CH questionnaire. In the group of boys, as expected, there were notable effects of the category that were found mainly on the subscales: Panic / Agoraphobia, Separation Anxiety, Social Phobia, Fear of Physical Injury and Generalized Anxiety Disorder. Boys with SLD showed statistically significantly higher values than their peers who did not have special educational needs. The only case in which students with SLD scored similar values to their peers without SLD was on the subscale of the symptoms of Obsessive/Compulsive Disorder in the SCAS-CH questionnaire. There are no relevant studies to explain this kind of symptoms in the whole student population. However, it should be noted that Mellon and Moutavelis (2007), using the same tool to detect anxiety problems in Greek students, found equally increased rates on this scale compared to other nationalities. This finding was attributed to cultural and religious peculiarities according to which Obsessive / Compulsive Disorder is considered more acceptable in Greek culture compared to other psychiatric disorders. 
Similarly, in the girls' subgroup, those female students who had SLD appeared to have higher rates on the Panic / Agoraphobia and Social Phobia scales, while there was no statistically significant effect of the category on the subscales of Separation Anxiety, Fear of Physical Injury, Obsessive/Compulsive Disorder, and Generalized Anxiety Disorder. In other words, the girls without SLD showed equally increased values on the specific subscales, a fact that did not agree with the entire foreign literature where girls with SLD are expected to be more prone to the onset of anxiety, anxiety disorders and internalized problems (Dahle, Knivsberg \& Andreason, 2011). Nevertheless, the increased values in Social Phobia for girls are justified, since according to Ollendick and colleagues (1998), girls with SLD tend to show higher rates of social fears, they are quite vulnerable to the social criticism of others, and emotionally more sensitive to negative criticism and comments.

Going further, to the exploration of the question "Is there a connection between negative thoughts and the appearance of anxiety symptoms in children with and without SLD?" it was found that children with SLD showed increased values on all scales of the CATS self-report questionnaire regarding negative internalized and externalized thoughts compared to their classmates without SLD. In particular, thoughts about Physical and Social Threat, as well as Hostility and Failure seem to have characterized largely students with SLD compared to their peers without. This expected result is in line with the research of Smith and Alloy, (2009) where a correlation between the greater severity and frequency of negative internalized and externalized thoughts in children with SLD was recorded. These children presented comorbidity with psycho-emotional / behavioral disorders such as anxiety and depression.

The aforementioned difference between children with and without SLD did not appear to be significantly influenced by factors such as the age or gender of the respondents. The lack of such findings, linking the age factor to negative self-reported thoughts, is contrasted to the findings of other studies to date. It would be expected for older children to have increased concerns about Social Threat and Failure compared to younger participants in the sample. This is probably due to the fact that some social concerns (e.g. social stigma) discouraged children from revealing the true size of the problem, as observed by Hogendoorn and his colleagues (2010).

In order to answer the question whether the negative self-report thoughts are directly related to the existence of SLD, we carried out correlation between the respective subscales of the CATS and SCAS-CH questionnaires. It was confirmed, by correlating the subscale of Social Threat with that of Social Phobia, that children who had scored high on one subscale, had scored high on the other as well. Therefore, students with SLD appeared to have had a higher incidence of negative thoughts than their normal development peers. This was in line with the findings of two studies by Muris, De Jong and his colleagues (2004) and Fresco and his colleagues (2002), who similarly found a link between negative thoughts and the onset of anxiety symptoms and depression in both childhood and adolescence. That happens to young people who experience intense social criticism, and difficulties / problems in their daily lives, just as is the case with students 
with SLD who every day have to fit to their environment and to meet the needs of the school curriculum.

Finally, regarding the research question: "Do the observations of parents and children with and without SLD agree regarding the identification of anxiety symptoms?", it was found that parents of children with SLD, who completed the questionnaire regarding the observation of the pattern of anxiety symptoms, noted higher values on almost all subscales compared to the parents of normal development children. In other words, there was a high degree of agreement between the answers of the children and their parents, a fact that could be attributed to the unified methodology used for data selection. This result was in complete agreement with the findings of Brown-Jacobsen, Wallace and Whiteside (2011), who observed significant agreement between parents and children, although their responses differed significantly for some symptoms.

The interesting thing here was that even when the age parameter was introduced as a variable in the analysis of variance, the results did not differ significantly. It appeared that the parents of children with SLD found out a greater influence of age on the 11-yearold subgroup of children in relation with the Category student; and that ascertainment concerned only the subscale of Physical Injury Fear in the SCAS-CH anxiety symptoms questionnaire. In the same line, gender also did not seem to have much effect on the results. Despite the lack of the aforementioned effects, there was a tendency of parents to score high in the subcategory of girls with and without SLD on the subscales Panic / Agoraphobia, Separation Anxiety, and Fear of Physical Injury, which may be due to the fact that usually these disorders manifest with symptoms that are more easily perceived by the parents themselves. In contrast, Generalized Anxiety Disorder and Obsessive/Compulsive Disorder show symptoms that are not easy for others to recognize (DeSousa, Pereira, Petersen, Manfro, Salum \& Koller, 2014). However, the fact that these symptoms were found also in girls without SLD made many researchers to try to explain it by focusing on the vulnerable and sensitive female nature that is considered more prone to the onset of similar symptoms and emergence of similar behaviors. In contrast, and as it was expected, lower levels of stress were found in boys (Ginsburg \& Silverman, 2000). In addition, the Greek parents of girls have some deep-rooted perceptions in their culture about family unity and that lead them to overestimate some symptoms in order to protect them. Finally, girls usually show a greater tendency to cling to their parents (Lewinsohn et al., 1998). In general, stress (internalized or externalized) seemed to be largely manifested in the female population, regardless of SLD (Carol et al., 2005).

The results of the present research should be studied taking into account the limited sample size from which the data were derived, as well as its heterogeneity in terms of the type of special learning disabilities. Although many scientists emphasize the importance of self-report tools for exploring stressful emotions, surely in this field of research we need much more studies that will combine self-reports and reports of 'significant others' namely parents and teachers, for an in-depth investigation of the relationship between SLD and anxiety disorders and negative thoughts especially in Greek-speaking Students. 


\section{Conflict of Interest Statement}

The authors declare no conflicts of interests.

\section{About the Authors}

Giannouli Vasiliki is an assistant professor at the Department of Special Education and Social Policy, Faculty of Social Humanities and Arts, University of Macedonia, Greece, the last six years. Her research interests are in areas of School Psychology, Specific Learning Disorders, ADHD, Psycho-emotional and Psychosocial development/adjustment of children with special education needs.

Sarris Dimitrios is an Assistant Professor, Department of Preschool Education, University of Ioannina, Greece. His research interests are Learning difficulties (evaluation-diagnosis-treatment), the evaluation of personality and intelligence, and the evaluation of children and adolescents with developmental disorders-psychopathology. $\mathrm{He}$ is also the director of the laboratory of Special and Therapeutic Education of the University of Ioannina, Greece.

Alexoudi Pagona was an MSc student at the Department of Special Education and Social Policy, Faculty of Social Humanities and Arts, University of Macedonia, Greece and she has successfully completed her Master Degree (Master of Science Degree without fees the acceptance of the attendees is ensured after their successful entry exams).

\section{Bibliography}

Achenbach, T. M., Dumenci, L., \& Rescola, L. A. (2003). DSM- Oriented and Empirically Based Approaches to Constructing Scales from the Same Intern Pools, Journal Clinical Child $\mathcal{E} \quad$ Adolescent Psychology, 32(3), 328-340. https://doi.org/10.1207/s15374424jccp3203 02

American Psychiatric Association. (2013). Diagnostic and statistical manual of mental disorders (5th ED.). Washington, DC. London, England: APA.

Anderson, J. C., Williams, S., McGee, R., \& Silva, P. A. (1987). DSM-III Disorders in Preadolescent Children: Prevalence in a Large Sample from the General Population. Arch Gen Psychiatry. 44(1):69-76. https://doi:10.1001/archpsyc.1987.01800130081010

Bakker, J. T. A., Denessen, E., Bosman, A. M. T., Krijger, E. M., \& Bouts, L. (2007). Sociometric Status and Self- Image of Children with Specific and General Learning Disabilities in Dutch General and Special Education Classes. Department of Special Education, 30 (1), 47-62. https://doi.org/10.2307/30035515

Barrett P. M., Healy-Farrell L., \& March J. S. (2004). Cognitive-behavioral family treatment of childhood obsessive compulsive disorder: a controlled trial. J. Am. Acad. Child Adolesc. Psychiatry, 43, 46-62. Retrieved from http://citeseerx.ist.psu.edu/viewdoc/download?doi=10.1.1.523.5226\&rep=rep1\&ty pe $=$ pdf 
Beck, A. T., Emery, G., \& Greenberg, R. L. (2005). Anxiety disorders and phobias: A cognitive perspective. Basic Books.

Bijtteber, P., Raes, F., Vasey, M. W., Blastin, M., Ehring, T. W. (2015). Assesment of Repetitive Negative Thinking in Children: the Perseverative Thinkinh Questionnaire - Child Version (PTQ-C). Journal of Behaviour Assessment, 37: 164170 DOI 10.1007/s10862-014-9446-x

Bonifacci, P., Storti, M., Tobia, V., \& Suardi, A. (2015). Specific Learning Disorders: A Look inside Children's and Parents' Psychological Well-Being and 89 Relationships. Journal of Learning Disabilities. 49(5):532-545. https://doi.org/10.1177/0022219414566681

Bonifacci, P., Tobia, V., Marra, V., Desideri, L., Baiocco, R., \& Ottaviani, C. (2020). Rumination and Emotional Profile in Children with Specific Learning Disorders and Their Parents. International Journal of Environmental Research and Public Health, 17(2), 389.

Bozas, A. A., Bonti, E., Kouimtzi, E. M., Kyritsis, Z., \& Karageorgiou, I. (2016). Psychosocial Functioning in Special Learning Difficulties: Self-Reports in a Sample of Greek adolescents with SLDs. International Journal of Education and Psychological Research, 5(4), 8-12. Retrieved from http://betamedarts.gr/wpcontent/uploads/2021/05/31Psychiatriki03 2020.pdf\#page $=46$

Brown-Jacobsen, A. M., Wallace, D. P., \& Whiteside S. P. H. (2011). Multimethod, Multiinformant Agreement, and Positive Predictive Value in the Identification of Child Anxiety Disorders Using the SCAS and ADIS-C. Assessment, 18(3):382-392. https://journals.sagepub.com/doi/pdf/10.1177/1073191110375792

Bukowski, W. M., Hoza, B., \& Boivin, M. (1993). Popularity, friendship and emotional adjustment during early adolescence. In B. Laursen (Ed.), Close friendships in adolescence, 23-37.

Burton, M., Kagan, C., \& Clements, P. (2013). Social skills for people with learning disabilities: A social capability approach. Springer.

Calvete, E., \& Connor-Smith, J. (2005). Automatic Thoughts and Psychological Symptoms: A Cross-Cultural Comparison of American and Spanish Students. Cognitive Therapy and Research, 29(2), 201-217. DOI: 10.1007/s10608-005-3165-2

Carol, J. M., \& Iles, J. E. (2006). An assessment of anxiety levels in dyslexic students in higher education. British Journal of Educational Psychology, 76, 651-662. DOI:10.1348/000709905X66233

Chien, W. T., \& Lee, I. Y. M. (2013). An explanatory Study of Parents' Perceived Educational Needs for Parenting a Child with Learning Disabilities. Asian Nursing Research, 7(1), 16-25. https://doi/pdf/10.1176/appi.ps.002092012

Dahle, A. E., Knivsberg, A. M., \& Andreassen, A. B. (2011). Coexisting problem behavior in severe dyslexia. Journal of Research in Special Educational Needs, 11(3), 162-170. DOI: 10.1111/j.1471-3802.2010.01190.x

Dalley, M. B., Bolocofsky, M. B, Alcorn, M. B. \& Baker, C. (1992). Depressive symptomatology, attributional style, dysfunctional attitude, and social 
competency in adolescents with and without learning disabilities. School Psychology Review, 21, 444-458. doi/abs/10.1080/02796015.1992.12085628

De Jong-Meyer, R., Beck, B., \& Riede, K. (2009). Relationships between rumination, worry, intolerance of uncertainty and metacognitive beliefs. Personality and Individual Differences, 46(4), 547-551. https://doi.org/10.1016/j.paid.2008.12.010

DeSousa, D. A., Pereira, A. S., Petersen, C. C., Manfro, G.G., Salum, G. A., \& Holler, S. H. (2014). Psychometric properties of the Brazilian-Portuguese version of the Spence Children's Anxiety Scale (SCAS): Self and parent report versions. Anxiety Disorders, 28(5), 427-436. https://dx.doi.org/10.1016/j.janxdis.2014.03.00620170906

Fisher, A., Schafer, B., Watcins, M., Worell, F. \& Hall, T. (2006). The factor structure of the fear survey schedule for children, II in Trinidadian children and adolescents. Journal of Anxiety Disorder, 20, 740-759. DOI:10.1016/janxdis.2005.11.003

Fresco, D., M., Frankel, A., N., Mennin, D., S., Turk, C., L., Heimberg, R., G. (2002). Distinct and Overlapping Features of Rumination and Worry: The Relationship of Cognitive Production to Negative Affective States. Cognitive Therapy and Research, 26, 179-188. https://doi.org/10.1023/A:1014517718949

Gibb, B. E., Grassia, M., Stone, L. B., Uhrlass, D.J \& McGeary, J. E. (2012). Brooding Rumination and Risk for Depressive Disorders in Children of Depressed Mothers. Journal of Abnormal Child Psychology, 40, 317-326. https://doi.org/10.1007/s10802-011-9554

Ginsburg, G., S. \& Silverman, W., K. (2000). Gender Role Orientation and Fearfulness in Children with Anxiety Disorders. Journal of Anxiety Disorders,14(1) 57-67. https://doi.org/10.1016/S0887-6185(99)00033-X.

Hogendoorn, S. M., Wolters, L. H., Vervoort, L., Prins, P. J. M., Boer, F., Kooij, E., \& de Haan, E. (2010). Measuring Positive and Negative Thoughts in Children: An adaptation of the Children's Automatic Thoughts Scale (CATS). 34, 467-478. DOI 10.1007/s10608-010-9306-2.

Kavale, K. A., 12, L. S., \& Beam, A. P. (2009). A Time to Define: Making Specific Learning Disability Definition Prescribe Specific Learning Disability. Learning Disability Quarterly, 32(1), 39-48. https://digitalcommons.liberty.edu/cgi/viewcontent.cgi?article=1125\&context=ed uc fac pubs

Lewisohn, P. M., Gotlib, I. H., Lewisohn, M., Selley, J. R, \& Allen, N. B. (1998). Gender differences in anxiety disorders and anxiety symptoms in adolescents. Journal of Abnormal Psychology, 107, 109-117

Li, H., \& Morris, R. J. (2007). Assessing fears and related anxieties in children and adolescents with learning disabilities or mild mental retardation. Research in developmental disabilities, 28(5), 445-457. https://doi.org/10.1016/j.ridd.2006.06.001

Lipscomb, S. T., Pratt, M. E., Schmitt, S. A., Pears, K. C. \& Kim, H. K. (2012). School readiness in children living in non-parental care: Impacts of head start. 
Margari, L., Buttiglione, M., Craig, Cristella, A., De Giambatista C., Matera, E., Operto, F., \& Simone, M. (2013). Neuropsychopathological comorbidities in learning disorders. BMC Neurology 13(198) https://doi.org/10.1186/1471-2377-13-198.

Maridaki-Kassotaki A. (2013). Educational Psychology. Athens: Diadrassi

Mather, N., \& Gregg, N. (2006). Specific learning disabilities: Clarifying, not eliminating, a construct. Professional Psychology: Research and Practice, 37(1), 99-106. https://doi.org/10.1037/0735-7028.37.1.99.

McCathie, H. \& Spence, S., H. (1991). What is the revised fear survey schedule for children measuring? Behaviour Research and Therapy, 29(5), 495-502. https://doi.org/10.1016/0005-7967(91)90134-O.

Mellon, R., \& Moutavelis, A. G. (2007). Structure, developmental course, and correlates of children's anxiety disorder-related behavior in a Hellenic community sample. Journal of Anxiety Disorders, 21, 1-21. doi:10.1016/j.janxdis.2006.03.008.

Mugnaimi, D., Lassi, S., La Malfa, G., \& Albertini, G. (2009). Internalizing Correlates of $\begin{array}{llll}\text { Dyslexia. World } \quad \text { Pediatr, } & \text { 5(4), }\end{array}$ https://link.springer.com/content/pdf/10.1007/s12519-009-0049-7.pdf

Nelson, J. M., \& Harwood, H. (2011). Learning disabilities and anxiety: A meta-Analysis. Journal of Learning Disability, 44(1), 3-17. DOI:10.1177/0022219409359939

Pham, A. V., Riviera, A. (2015). Specific Learning Disorders and ADHD: Current Issues in Diagnosis Across Clinical and Educational Settings. Curr Psychiatry Rep, 17(38). DOI 10.1007/s11920-015-0584-y

Polychroni F. \& Chatzichristou X. \& Mimbou A. (2010). Special Learning Disabilities Dyslexia Classification, Assessment and Intervention $4^{\text {th }}$ edition: Publications: Ellinika Grammata

Polychroni, F., Koukoura, K. \& Anagnostou, I. (2006). Academic self-concept, reading attitudes and approaches to learning of children with dyslexia: do they differ from their peers? European Journal of Special Needs Education, 21(4), 415- 430, DOI: 10.1080/08856250600956311

Rubin, K. H., Bukowski, W., \& Parker, J. (1998). Peer interactions, relationships, and groups. In W. Damon \& N. Eisenberg (Eds), Handbook of child psychology (5th ed., pp. 619-700). New York: Wiley.

Schaefer, B. A., Watcins, M. W., \& Burnham, J. J. (2003). Empirical fear profiles among American youth. Behaviour Research and Therapy, 41, 1093-1103 DOI:10.1016/S0005-7967(02)00258-9

Schniering,C., A. Rapee, R.M. (2002) Development and validation of a measure of children's automatic thoughts: the children's automatic thoughts scale, Behaviour Research and Therapy, Volume 40, Issue 9, Pages 1091-1109, https://doi.org/10.1016/S0005-7967(02)00022-0.

Silverman, W. K., \& Field, A.P. (2011). Anxiety Disorders in Children and Adolescents. Second Edition. University Press, Cambridge. 
Smith, J., \& Alloy, L. B. (2009). A roadmap to rumination: A review of the definition, assessment, and conceptualization of this multifaceted construct. Clinical Psychology Review, 29(2), 116-128. https://doi.org/10.1016/j.cpr.2008.10.003

Spence, S. (1998). A measure of anxiety symptoms among children. Behavior Research and Therapy, 36, 545-566.

Swanson, H.L., Zheng, X., Jerman, O. (2009). Working memory, short-term memory, and reading disabilities: a selective meta-analysis of the literature. Journal of Learning Disabilities, May-June 2009, 42(3): 260-87. DOI:10.1177/0022219409331958

Thaler, N. S., Kazemi, E., \& Wood, J. J. (2010). Measuring anxiety in youth with learning disabilities: reliability and validity of the Multidimensional Anxiety Scale for Children (MASC). Child Psychiatry \& Human Development, 41(5), 501-514. ) DOI 10.1007/s10578-010-0182-5

Triga, E. (2010). Learning Disabilities. General and special learning Disabilities - Dyslexia. Athens: Grigoris.

Tzouriadou, M. (2011). Learning difficulties. Interpretation and handling. Thessaloniki: Prometheus.

Verstraeten, K., Bijttebier, P., Vasey, M. W., \& Raes, F. (2011) Specificity of worry and rumination in the development of anxiety and depressive symptoms in children. British Journal of Clinical Psychology, 50(4), 364-378. https://doi.org/10.1348/014466510X532715

Visser L., Kalmar J., Linkersdörfer J., Görgen R, Rothe J., Hasselhorn M. \& Schulte-Körne G. (2020). Comorbidities Between Specific Learning Disorders and Psychopathology in Elementary School Children in Germany. Front. Psychiatry, 11:292. DOI: 10.3389/fpsyt.2020.00292

Weems, C. F., \& Costa, N. M., (2005). Developmental Differences in the Expression of Childhood Anxiety Symptoms and Fears. Journal of the American Academy of Child and Adolescent Psychiatry, 44(7), 656-663. DOI: 10.1097/01.chi.0000162583.25829.4b

Zakopoulou,V., Mavreas, V., Christodoulides, P., Lavidas, A., Fili, E., Georgiou, G., Dimakopoulos, G. \& Vergou, M. (2014). Specific learning difficulties: A retrospective study of their co morbidity and continuity as early indicators of mental disorders. Researching Developmental Disabilities, 35(12), 3496-3507. https://doi.org/10.1016/j.ridd.2014.07.040 
Giannouli Vasiliki, Sarris Dimitrios, Alexoudi Pagona

ANXIETY DISORDERS AND THE FREQUENCY OF NEGATIVE THOUGHTS:

A COMPARATIVE STUDY IN CHILDREN WITH AND WITHOUT SPECIAL LEARNING DISABILITIES

Creative Commons licensing terms

Authors will retain the copyright of their published articles agreeing that a Creative Commons Attribution 4.0 International License (CC BY 4.0) terms will be applied to their work. Under the terms of this license, no permission is required from the author(s) or publisher for members of the community to copy, distribute, transmit or adapt the article content, providing a proper, prominent and unambiguous attribution to the authors in a manner that makes clear that the materials are being reused under permission of a Creative Commons License. Views, opinions and conclusions expressed in this research article are views, opinions and conclusions of the author(s). Open Access Publishing Group and European Journal of Special Education Research shal not be responsible or answerable for any loss, damage or liability caused in relation to/arising out of conflict of interests, copyright violations and inappropriate or inaccurate use of any kind content related or integrated on the research work. All the published works are meeting the Open Access Publishing requirements and can be freely accessed, shared, modified, distributed and used in educational, commercial and non-commercial purposes under a Creative Commons Attribution 4.0 International License (CC BY 4.0). 